MATH DIDACTIC: JURNAL PENDIDIKAN MATEMATIKA

Volume 4 Nomor 3 September - Desember 2018, halaman 235 - 242

Tersedia Daring pada http://jurnal.stkipbjm.ac.id/index.php/math

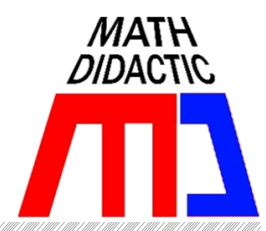

\title{
KECENDERUNGAN TINGKAT KETERAMPILAN BERPIKIR SISWA SMA MENURUT TAKSONOMI BLOOM DAN KAITANNYA DENGAN GENDER
}

\section{TRENDS OF THINKING SKILLS LEVEL ABOUT HIGH SCHOOL STUDENTS BY TAXONOMY BLOOM AND ITS CONNECTION WITH GENDER}

\author{
Rolina Amriyanti Ferita, Mia Fitria \\ Universitas Nahdlatul Ulama Kalimantan Selatan \\ rolinaamriyantiferita@gmail.com,mia.fitria87@gmail.com
}

\begin{abstract}
Abstrak: penelitian ini bertujuan untuk mendapatkan gambaran mengenai tingkat keterampilan berpikir siswa SMA ditinjau dari taksonomi Bloom versi revisi dan melihat kaitannya dengan jenis kelamin. Jenis penelitian yang dilakukan adalah Deskriptif Kuantitatif dengan pendekatan Ex Post Facto, yaitu penelitian yang dilakukan untuk meneliti peristiwa yang telah terjadi yang kemudian merunut ke belakang untuk mengetahui faktor-faktor yang dapat menimbulkan kejadian tersebut. Peristiwa yang dimaksud dalam penelitian ini adalah HOTS siswa, sedangkan faktor yang dapat menimbulkan kejadian tersebut adalah gender. Hasil penelitian menunjukkan bahwa tidak ada hubungan antara tingkat keterampilan berpikir siswa dengan jenis kelaminnya.
\end{abstract}

Kata Kunci: tingkat keterampilan berpikir, taksonomi bloom, jenis kelamin

\begin{abstract}
This study aims to get an overview of the level of thinking of high school students in terms of Bloom's revised taxonomy and see its relation to gender. The type of research conducted is Quantitative Descriptive with the Ex Post Facto approach, which is research conducted to examine events that have occurred which then traces back to find out the factors that can lead to these events. The event referred to in this study is HOTS students, while the factors that can lead to these events are gender. The results showed that there was no relationship between the level of students' thinking skills and their gender.
\end{abstract}

Keywords: thinking skills level, bloom taxonomy, gender

Cara Sitasi: Ferita, R.A., \& Fitria, M. (2018). Kecenderungan tingkat keterampilan berpikir siswa SMA menurut taksonomi bloom dan kaitannya dengan gender. Math Didactic: Jurnal Pendidikan Matematika, 4(3), $235-242$. 
Pendidikan bertujuan untuk mendidik siswa agar mampu beradaptasi di berbagai kondisi, berpikir fleksibel, memiliki rasa ingin tahu yang tinggi, kreatif, kritis, dapat menyelesaikan masalah, menghargai sesama, dan memiliki toleransi terhadap gagasan orang lain (Aktamis \& Yenice, 2010, hal. 3282). Di Indonesia, kurikulum 2013 yang tengah diterapkan saat ini sangat memfokuskan pada pengembangan keterampilan berpikir tingkat tinggi (Higher-Order Thinking Skills). Hal ini dapat dilihat pada Lampiran Permendikbud Tahun 2016 Nomor 22 (Mendikbud, 2016, hal. 3). Higher-Order Thinking Skills (HOTS) pada lampiran tersebut sesuai dengan penjelasan Anderson \& Krathwohl (2001, hal. 28) yaitu terdiri atas mengingat, memahami, mengaplikasikan, menganalisis, mengevaluasi, dan mencipta. Akan tetapi, para guru menganggap bahwa HOTS tidak cocok untuk siswa yang memiliki kemampuan akademik rendah (Zohar, Degani, \& Vaaknin, 2001, hal. 469).

Padahal, pembelajaran yang difokuskan untuk peningkatan HOTS mampu menjadikan HOTS siswa pada semua kemampuan akademik meningkat (Brookhart \& Nitko, 2007, hal. 65). Sejalan dengan ini, King, Goodson, \& Rohani (2010, hal. 1) menegaskan bahwa HOTS siswa teraktivasi ketika mereka menemui masalah yang asing, tidak pasti, dan membingungkan. Ormrod (2003, hal. 296) menambahkan bahwa strategi umum dalam meningkatkan HOTS yaitu melalui: (1) penekanan pada pembelajaran bermakna (meaningful learning) dan pemahaman konsep dibanding sekedar menghafal; (2) pengajaran HOTS dengan topik yang spesifik dan kontekstual; (3) penjelasan bahwa hasil akhir yang berbeda dapat menjadi tambahan ilmu baru; (4) dorongan HOTS dalam diskusi kelompok atau proyek bersama;
(5) pembiasaan HOTS di sekolah; dan (6) penyertaan HOTS ke dalam penilaian aktivitas.

Berangkat dari hasil PISA (Program for International Students Assessment) 2015 yang digagas oleh OECD (Organization for Economic Cooperation and Development) yang sangat berkaitan dengan HOTS, performa siswa yang mewakili Indonesia mengalami peningkatan khususnya di bidang matematika yaitu menjadi peringkat 63 dari 69 negara, yang sebelumnya pada 2012 berada pada peringkat 64 dari 65 negara yang berpartisipasi (Iswadi, 2016, hal. 1). Meskipun hasil ini masih tergolong rendah, analisis dari Biro Komunikasi dan Layanan Masyarakat Kementrian Pendidikan dan Kebudayaan (2016, hal. 1) menjelaskan bahwa sedikitnya ada tiga aspek yang mempengaruhi hasil PISA 2015 di Indonesia, yaitu aspek peranan Kepala Sekolah yang menunaikan tanggung jawabnya atas tata kelola sekolah yang baik, aspek status sekolah dimana 6 dari 10 kontributor siswa yang menjawab soal PISA berasal dari sekolah negeri, dan aspek latar belakang sosial ekonomi dimana 3 dari 4 siswa kontributor memiliki orang tua dengan latar belakang sosial ekonomi yang baik. Lalu bagaimana dengan gender? Sudahkah Kurikulum 2013 diterapkan dengan baik oleh guru? Atau bahkan apakah Kurikulum 2013 sendiri yang belum secara maksimal mendorong peningkatan HOTS siswa?.

Konsep awal dari HOTS diperoleh dari Taksonomi Bloom yaitu pengetahuan, pemahaman, aplikasi, analisis, sintesis, dan evaluasi (Forehand, 2005, hal. 1). Taksonomi ini kemudian direvisi menjadi mengingat, memahami, mengaplikasikan, menganalisis, mengevaluasi, dan mencipta (Anderson \& Krathwohl, 2001, hal. 28). 
Taksonomi Bloom menurut Pappas et al (Saido, Siraj, Nordin, \& Al-Amedy, 2015, hal. 14) tersusun mulai dari yang paling konkret sampai yang paling abstrak. Susunan ini menunjukkan proses kognitif dari tingkat rendah sampai ke tingkat yang paling tinggi (Clark, 2015, hal. 1). Tiga tingkat pertama dalam Taksonomi Bloom yaitu mengingat, memahami, dan mengaplikasikan termasuk dalam Keterampilan Berpikir Tingkat Rendah (Lower-Order Thinking Skills), sedangkan tiga tingkat terakhir dari Taksonomi Bloom yaitu menganalisis, mengevaluasi, dan mencipta dikategorikan sebagai HOTS (Yahya, Toukal, \& Osman, 2012, hal. 135).

Penilaian adalah proses pengumpulan dan pengolahan informasi untuk mengukur pencapaian hasil belajar siswa (Presiden Republik Indonesia, 2013, hal. 5). Penilaian hasil belajar siswa pada jenjang pendidikan dasar dan menengah didasarkan pada prinsipprinsip dari Permendikbud No. 66 Tahun 2013 tentang Standar Penilaian (Kementrian Pendidikan dan Kebudayaan, 2013, hal. 3), yaitu objektif, terpadu, ekonomis, transparan, akuntabel, dan edukatif. Permendikbud No. 66 Tahun 2013 (Kementrian Pendidikan dan Kebudayaan, 2013, hal. 4) juga menjelaskan bahwa pendidik menilai kompetensi pengetahuan melalui tes tulis, tes lisan, dan penugasan.

Gronlund, Linn, \& Miller (2009, hal. 139-169), menyatakan bahwa dalam perencanaan tes melibatkan hal-hal sebagai berikut.

a. Menentukan tujuan pengukuran.

b. Mengembangkan satu set spesifikasi/acuan.

c. Memilih jenis soal tes yang tepat.

d. Menyiapkan satu set item yang relevan.
Alat ukur HOTS dalam penelitian ini menggunakan tes tertulis bentuk pilihan ganda dan uraian. Menurut Kartowagiran (2012, hal. $3)$, pengembangan soal tes baik tes bentuk pilihan ganda maupun uraian terdiri atas: (1) penentuan tujuan tes; (2) penyusunan kisi-kisi; (3) penulisan soal; (4) penelaahan soal (review dan revisi soal); (5) uji coba soal, termasuk analisis dan perbaikan; dan (6) perakitan soal menjadi perangkat tes.

Tes pilihan ganda lebih baik daripada tes uraian dalam hal banyaknya jumlah pokok bahasan yang ditanyakan, lebih menekankan kepada keluasan materi, serta mudah dan konsisten dalam hal penskoran (Kartowagiran, 2012, hal. 13). Sedangkan menurut Reynolds, Livingston, \& Willson (2009, hal. 224) tes uraian memiliki kelebihan yaitu menyediakan kebebasan kepada siswa untuk menuliskan jawaban mereka, dapat memberikan pengalaman baru serta proses kognitif peserta didik yang kreatif. Tambahan lagi, tes uraian yang baik menantang peserta didik untuk mengorganisasi, menganalisis, mengintegrasi dan menyintesis informasi yang ada.

\section{Metode Penelitian}

Jenis penelitian yang dilakukan adalah Deskriptif Kuantitatif dengan pendekatan Ex Post Facto, yaitu penelitian yang dilakukan untuk meneliti peristiwa yang telah terjadi yang kemudian merunut ke belakang untuk mengetahui faktor-faktor yang dapat menimbulkan kejadian tersebut. Peristiwa yang dimaksud dalam penelitian ini adalah HOTS siswa, sedangkan faktor yang dapat menimbulkan kejadian tersebut adalah gender. HOTS siswa juga akan dijelaskan secara deskriptif dan mendalam. Penelitian ini akan dilaksanakan pada awal tahun ajaran baru 2018/2019. 
Populasi dalam penelitian ini adalah seluruh siswa SMA Negeri kelas X di kota Banjarmasin. Karena populasi dari seluruh siswa lebih dari 20000 orang, maka sampel yang diambil minimal 377 siswa dengan derajat kepercayaan $95 \%$ dan distribusi respon 50\% laman http://www.raosoft.com/samplesize.html.

Akan tetapi jumlah ini merupakan jumlah minimal yang dapat dijadikan sampel (Krejcie \& Morgan, 1970, hal. 608). Untuk mengurangi kesalahan dan meningkatkan reliabilitas data yang diambil maka peneliti menargetkan sampel minimal 384 siswa. Sampel ini akan diambil dari 6 SMA Negeri yang dipilih secara random, kemudian dari tiap sekolah diambil 2 kelas secara random dengan jumlah siswa per kelas minimal 32 orang sebagaimana jumlah siswa SMA yang ideal/per kelas sesuai Peraturan Pemerintah nomor 23 tahun 2013 pasal 2 poin 2.

Instrumen penelitian yang digunakan adalah tes tertulis berbentuk pilihan ganda. Tes pilihan ganda ini dirancang sesuai Taksonomi Bloom versi revisi yang terdiri atas 6 tingkat (mengingat, memahami, mengaplikasikan, menganalisis, mengevaluasi, dan mencipta). Tes ini akan dibuat sebanyak 24 soal, dengan proporsi masing-masing tingkat berpikir adalah 4 soal. Banyaknya pilihan pada setiap soal adalah 4, sesuai dengan Standar Nasional untuk SMA.

Instrumen penelitian ini terlebih dahulu dirancang dengan prosedur yang akan menjamin keabsahan data yang diambil. Prosedur yang dilakukan sebagai berikut.

a. Melakukan telaah terhadap Kompetensi Dasar (KD) yang akan diukur

b. Membuat Indikator yang merupakan turunan dari KD, dengan berpedoman pada kata kerja untuk Taksonomi Bloom seperti pada Tabel 2.

c. Merancang draf soal

d. Mengecek validitas draf soal menurut ahli materi dan ahli evaluasi

e. Melakukan revisi sesuai masukan validator

f. Melakukan uji coba pada siswa di sekolah yang bukan bagian dari sampel penelitian

g. Melakukan Analisis Butir Soal dari hasil uji coba tersebut

h. Hasil uji coba juga digunakan untuk mengetahui apakah waktu yang disediakan sebanyak 2X40 menit cukup untuk menjawab soal

i. Melakukan perbaikan sesuai hasil uji coba

j. Memperoleh soal tes pilihan ganda versi final

Data penelitian ini dikumpulkan melalui Tes Tertulis berbentuk pilihan ganda yang sudah valid, reliabel, memiliki tingkat kemudahan dan daya pembeda yang baik, serta memiliki distraktor yang berfungsi seluruhnya. Penskoran mengikuti aturan bahwa diberi skor satu jika soal dijawab dengan benar dan nol jika soal dijawab salah, tidak dijawab, atau jawaban lebih dari satu.

Tes yang akan digunakan adalah tes tertulis berbentuk pilihan ganda. Sebelum digunakan, tes ini diuji validitasnya. Uji validitas yang digunakan adalah validitas isi dan validitas konstruk. Validitas isi dihitung melalui validasi ahli menggunakan lembar validasi yang diambil dari dua orang ahli, yaitu ahli materi dan ahli evaluasi. Berdasarkan CVR (Content Validity Ratio) yang dikemukakan oleh Lawshe (1975, hal. 568) bahwa jika ahli yang digunakan berjumlah 2 orang maka keduanya harus menemui 
kesepakatan bahwa tiap item tes valid, jika tidak valid maka harus dilakukan perbaikan.

Untuk validitas konstruk, peneliti menggunakan bantuan aplikasi SPSS versi 23 . Uji validitas yang digunakan adalah validitas Product Moment Pearson Correlation dengan prinsip mengorelasikan atau menghubungkan antara masing-masing skor item dengan skor total yang diperoleh. Untuk uji estimasi reliabilitas, peneliti menggunakan formula Alpha Cronbach melalui aplikasi SPSS versi 23.

Statistik deskriptif digunakan untuk menjelaskan tentang keterampilan berpikir siswa, serta kecenderungan tingkat berpikir siswa. Untuk hal ini, statistik yang dipakai adalah rerata (mean), standar deviasi, jangkauan (range), dan median. Akan tetapi sebelum itu, perlu diidentifikasi apakah data yang didapat berdistribusi normal atau tidak dengan menghitung nilai kecondongan (skewness) dan keruncingan (kurtosis). Perhitungan ini menggunakan aplikasi SPSS versi 23. Menurut Hair, Black, Babin, \& Anderson (2010, hal. 71), data berdistribusi normal jika nilai $\mathrm{z}$ untuk kecondongan dan keruncingan terletak di antara $\pm 1,96$ dengan derajat signifikansi 0,05. Dengan kata lain, nilai kecondongan dan keruncingan yang berada di antara \pm 1 menunjukkan data berdistribusi normal (Saido, Siraj, Nordin, \& Al-Amedy, 2015, hal. 16).

Uji Chi kuadrat digunakan untuk menentukan ada tidaknya hubungan gender terhadap HOTS siswa. Derajat signifikansi yang digunakan untuk uji ini adalah 0,05. Uji ini dilakukan dengan bantuan aplikasi SPSS versi 23 dan MS Excel 2013.

\section{Hasil Penelitian dan Pembahasan}

Kegiatan penelitian diawali dengan pembuatan instrumen penelitian berupa tes tertulis berbentuk pilihan ganda sebanyak 24 soal. Draft soal ini kemudian divalidasi oleh dua orang ahli, yaitu ahli materi dan ahli evaluasi. Hasil revisi berdasarkan masukan validator selanjutnya diuji cobakan ke sekolah untuk mendapatkan data validitas empiris dan estimasi reliabilitasnya. Skor korelasi Pearson untuk hasil validitas empiris menunjukkan bahwa soal nomor 13, 17, dan 24 tidak valid.

Perhitungan statistik selanjutnya adalah estimasi reliabilitas menggunakan Alpha Cronbach dengan hasil bahwa secara keseluruhan instrumen penelitian berupa soal pilihan ganda yang valid juga memiliki reliabilitas tinggi berupa 0,818 . Hal ini diperoleh dengan membuang soal nomor 2,5 , dan 10 juga karena instrumen yang diperlukan memang hanya 18 soal.

Instrumen yang sudah valid dan reliabel ini kemudian digunakan untuk pengambilan data penelitian. Sampel yang diambil dalam penelitian ini adalah siswa kelas $X$ yang berada di SMAN 12, SMAN 13, SMAN 6, SMAN 1, SMAN 4, dan SMAN 3. Total sampel yang diperoleh adalah 404 siswa yang terbagi menjadi 138 siswa laki-laki dan 266 siswa perempuan. Adapun hasil yang diperoleh secara umum dapat dilihat pada Tabel 1.

Tabel 1. Statistik Deskriptif Tingkat Keterampilan Berpikir Siswa

\begin{tabular}{ccccc}
\hline Tingkat & $\begin{array}{c}\text { Rata- } \\
\text { rata }\end{array}$ & Variansi & Skewness & Kurtosis \\
\hline C1 & 2,3366 & 0,532 & $-0,886$ & 0,353 \\
\hline C2 & 1,7054 & 0,779 & $-0,237$ & $-0,642$ \\
\hline C3 & 1,2921 & 1,230 & 0,303 & $-1,250$ \\
\hline C4 & 1,7351 & 0,905 & $-0,144$ & $-0,977$ \\
\hline C5 & 1,2153 & 0,859 & 0,161 & $-0,950$ \\
\hline C6 & 1,8342 & 1,052 & $-0,509$ & $-0,858$ \\
\hline
\end{tabular}


Pada Tabel 1 terlihat bahwa skor ratarata siswa yang tertinggi berada pada tingkat keterampilan berpikir Mengingat yaitu sebesar 2,3366 dari skor maksimum 3, sedangkan skor rata-rata terendah siswa berada pada tingkat Mengevaluasi yaitu sebesar 1,2153 dari skor maksimum 3. Hasil ini menunjukkan bahwa secara umum keterampilan berpikir siswa masih cenderung rendah atau termasuk kategori LOTS. Hasil ini dapat digeneralisasi karena skor skewness dan kurtosis dari masing-masing tingkat keterampilan berpikir berada di antara $\pm 1,96$ yang berarti data berdistribusi normal.

\section{Simpulan dan Saran}

Kesimpulan dan saran yang dapat diberikan berdasarkan hasil penelitian ini adalah bahwa keterampilan berpikir siswa SMA Negeri di kota Banjarmasin masih cenderung rendah, sehingga perlu usaha agar dapat meningkat. Salah satu alternatif yang disarankan adalah penggunaan pendekatan pembelajaran berbasis masalah atau $\mathrm{PBL}$ (problem-based learning) karena berdasarkan hasil penelitian dari Riadi (2016) bahwa PBL mampu meningkatkan HOTS siswa.

\section{Daftar Pustaka}

Aktamis, H., \& Yenice, N. (2010). Determination of the science process skills and critical thinking skill levels. Procedia Social and Behavioral Sciences(2), 3282-3288.

Anderson, O. W., \& Krathwohl, D. R. (Penyunt.). (2001). A taxonomy for learning, teaching, and assessing: $A$ revision of Bloom's taxonomy of educational objectives. New York: Addison Wesley Longman, Inc.

Biro Komunikasi dan Layanan Masyarakat Kementrian Pendidikan dan Kebudayaan. (2016, December 6). Peringkat dan capaian PISA Indonesia mengalami peningkatan. Diambil kembali dari Laman Kementrian Pendidikan dan Kebudayaan: https://www.kemdikbud.go.id/main/bl og/2016/12/peringkat-dan-capaianpisa-indonesia-mengalamipeningkatan

Brookhart, S. M., \& Nitko, A. J. (2007). Assessment and grading in classroom. Upper Saddle River, New Jersey: Pearson Education, Inc.

Clark, D. (2015, January 12). Bloom's taxonomy of learning domains. Diambil kembali dari A Big Dog, Little Dog, and Knowledge Jump Production: http://www.nwlink.com/ donclark/hrd /bloom.html

Forehand, M. (2005). Bloom's taxonomy. Dipetik June 9, 2017, dari Emerging Perspectives on Learning, Teaching, and Technology: http:/epltt.coe.uga.edu/index.php?title $=$ Bloom $\% 27$ s_Taxonomy

Gronlund, Linn, \& Miller. (2009). Measurement and assessment in teaching. Upper Saddle River, New Jersey: Pearson Education, Inc.

Hair, J. F., Black, W. C., Babin, B. J., \& Anderson, R. E. (2010). Multivariate 
data analysis (7th ed.). Upper Saddle River, New Jersey: Pearson.

Iswadi, H. (2016, December 7). Sekelumit dari hasil PISA 2015 yang baru dirilis. Diambil kembali dari Laman Universitas Surabaya: http://www.ubaya.ac.id/2014/content/ articles_detail/230/Overview-of-thePISA-2015-results-that-have-justbeen-Released.html

Kartowagiran, B. (2012). Penulisan butir soal. Yogyakarta: Universitas Negeri Yogyakarta.

Kementrian Pendidikan dan Kebudayaan. (2013). Peraturan menteri pendidikan dan kebudayaan nomor 66 tahun 2013 tentang standar penilaian. Jakarta: Kementrian Pendidikan dan Kebudayaan.

King, F. J., Goodson, L., \& Rohani, F. (2010). Assessment \& evaluation educational services program: Higher order thinking skills. Washington, DC: Educational Services Program.

Krejcie, R. V., \& Morgan, D. W. (1970). Determining sample size for research activities. Educational dan Psychological Measurement(30), 607610.

Lawshe, C. H. (1975). A quantitative approach to content validity. Personnel Psychology(28), 563-575.

Mendikbud. (2016). Lampiran permendikbud tahun 2016 nomor 22. Jakarta: Kementerian Pendidikan dan Kebudayaan Republik Indonesia.
Ormrod, J. E. (2003). Educational psychology: Developing learners. Upper Saddle River, New Jersey: Pearson Education, Inc.

Presiden Republik Indonesia. (2013). Peraturan pemerintah nomor 32 tahun 2013 tentang perubahan atas peraturan pemerintah nomor 19 tahun 2005 tentang standar nasional pendidikan. Jakarta: Presiden Republik Indonesia.

Reynolds, C. R., Livingston, R. B., \& Willson, V. (2009). Measurement and assessment in education (2nd ed.). Upper Saddle River, New Jersey: Pearson Education, Inc.

Riadi, A. (2016). Problem-based learning meningkatkan higher-order thinking skills siswa kelas VIII SMPN 1 Daha Utara dan SMPN 2 Daha Utara. Math Didactic: Jurnal Pendidikan Matematika, 2(3), 154-163.

Saido, G. M., Siraj, S., Nordin, A. B., \& AlAmedy, O. S. (2015). Higher order thinking skills among secondary school students in science learning. The Malaysian Online Journal of Educational Science, III(3), 13-20.

Yahya, A. A., Toukal, Z., \& Osman, A. (2012). Bloom's taxonomy-based classification for item bank questions using support vector machines. Dalam W. Ding, H. Jiang, M. Ali, \& M. Li, Modern advances in intelligents systems and tools (hal. 135-140). Berlin: Springer.

Zohar, A., Degani, A., \& Vaaknin, E. (2001). Teachers' beliefs about low-achieving 
students and higher order thinking.

Teaching and Teacher Education(17), 469-485. 